\title{
CONNECTION CAPACITY OF THE TRANSITION ZONE IN STEEL-CONCRETE HYBRID BEAM
}

\author{
Piotr KOZIOŁ ${ }^{1}$, Maciej KOŻUCH, Wojciech LORENC, \\ Sławomir ROWIŃSKI \\ Wroclaw University of Technology, Wrocław, Poland
}

\begin{abstract}
The problem of transition zone of structural steel element connected to concrete is discussed in the following paper. This zone may be located for instance in specific bridge composite girder. In such case the composite beam passes smoothly into concrete beam. Because of several dowels usage in the transition zone, the problem of uneven force distribution were discussed through analogy to bolted and welded connections. The authors present innovative solution of transition zone and discuss the results, with emphasis put on the transition zone structural response in term of bending capacity, failure model and force distribution on the connection length. The article wider the already executed experimental test and presents its newest results.
\end{abstract}

Keywords: transition zone, hybrid beam, perfobond connectors, destructive tests, composite structures

\section{INTRODUCTION}

In 2009, within the S5 expressway line, the road bridge WD4 was built with application of innovative technology. The bridge carries both, S5 expressway interchanges, between Stryszek and Białe Błota, and access road over the railway track. The bridge was designed as a frame structure. Prefabricated elements with steel T-section profiles, embedded in concrete plate, were used as external reinforcement of bridge's deck. The key point was the fact that steel sections do

1 Corresponding author: Wroclaw University of Technology, Faculty of Civil Engineering, Wybrzeże Wyspiańskiego 27, 50-377 Wrocław, Poland, e-mail: piotr.koziol@pwr.edu.pl, tel. +48773203420 
not run over the entire bridge span but terminate near zero bending moment zone. The bottom view of WD4 bridge is shown in Figure 1. The continuous shear connection was realized with composited dowels of MCL shape [2, 3, 9]. The bridge design and its construction are described in detail in [12].
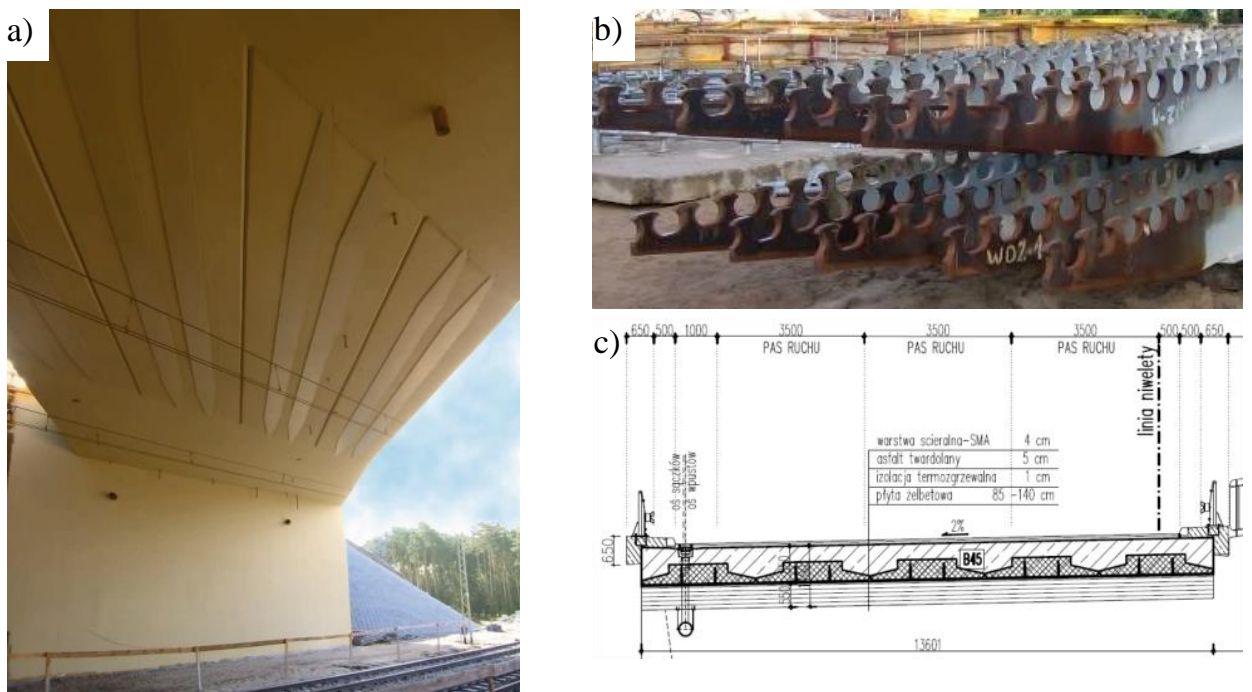

Fig. 1. First application of the hybrid beam with transition zone: a) bottom view on WD4 viaduct built along the expressway S5 over the railway line No. 131, b) transition zone in steel part before prefabrication, c) cross-section in the middle-span of the WD4 viaduct

WD4 road bridge was the first construction with steel-concrete hybrid beam solution application. The hybrid beam is the composite beam with continuous shear connectors used, which passes smoothly into concrete beam using innovative solution of transition zone. In transition zone, both steel web and flange are reduced until the ending of the steel part. Normal force is being transferred from steel part to concrete with the group of connectors (dowels), i.e. holes in steel web filled with concrete.

Implementing the new solution in construction is challenging on each stage starting from difficulties in designing and calculating the capacity of the structure to prefabrication methods on site. One of the crucial aspects of construction was the transition zone of steel profiles. The construction of the bridge has been widely discussed at different practitioners' and scientists' meetings as well as conferences. In accordance with numerous doubts and lack of tests' results, the following research has been conducted. It aims to provide the solution resulting in the length of transition zone reduction and limitation of the rapid change in stiffness related to the ending of the steel part. Different conceptions for transition zone including solution with the MCL dowels situated on the top of steel web and 
a round or oval holes in the steel web were taken into account and shown in Figure 2.
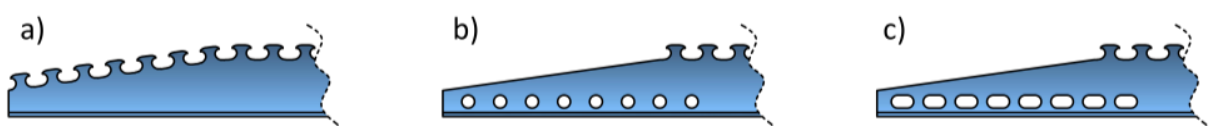

Fig. 2. Different solutions of the transition zone based on: a) contionous connectors MCL, b) round holes in the steel web, c) oval holes in the steel web

Among different conceptions, the connection with closed holes as analogy to the perfobond rib connectors was chosen [7]. It was decided to situate the perfobond holes in bottom part of steel section web, near the bottom flange. Consequently, the destructive test was planned and beam specimen with testing programmes were developed. The element for test was designed according to the recommendations suggested in EN 1994-1-1 and other approved testing procedures appropriate for composite steel and concrete structures $[8,10,11]$. The cross-sectional dimensions of the beams correspond to a half-scale of beams applied in constructions.

In particular, the main objective of the destructive test was to estimate flexural carrying capacity of the beam subjected to a positive bending moment. The point of reference, when interpreting the results, was the bending moment capacity of the beam conditioned by failure of transition zone. Load capacity of whole element was compared with load capacity of both composite and concrete sections situated outside the transition zone - in support sections. Another objective to be obtained was to determine the failure mechanism of transition zone. The following paper presents a beam specimens design, the research which has been conducted and the first key test results.

\section{DISTRIUBITON OF FORCES IN LONG CONNECTIONS}

Once designing the transition zone of hybrid beam, there is a need to use several connectors in one joint which leads to the problem of long connections. Finding the solution for uneven force distribution become a key point when desiging the transion znone, however the phenomena is typical for steel structures and used to lead to overload of the connectors at the ends of the joint. The distribution can be easily demonstrated when two theoretical (extreme) situations are compared either the infinitely stiff connectors and weak plates or infinitely stiff plates and weak connectors.

In case of stiff connectors model and weak plates material (Fig. 3b), while loading the bolts do not deform, on the contrary they stay straight and parallel to each other. External connectors carry the total force $\mathrm{F}$ and internal connectors are not loaded. Plates between the connectors are under the same strains and carry the 
constant force. The other case, assuming the stiff model of plates' material and weak connectors model (Fig. 3c), results with undeformed plates between the bolts. Each connectors has the same deformation and therefore carry the same force.

The real force distribution is between these two extreme cases with similar connectors stiffness to plates one (Fig. 3d). Consequently, based on the elastic behaviour, force in each connector is different because of different plates elongations between connectors. The differences are bigger in the outer parts of joints as compared to inner part. Thus, the force in outer connectors is bigger than inner ones (Fig. 3e).

a)

b)

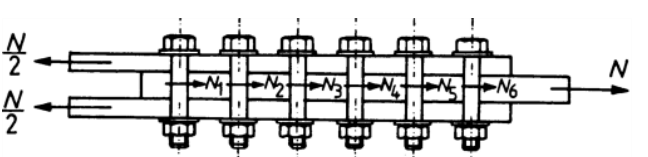

c)

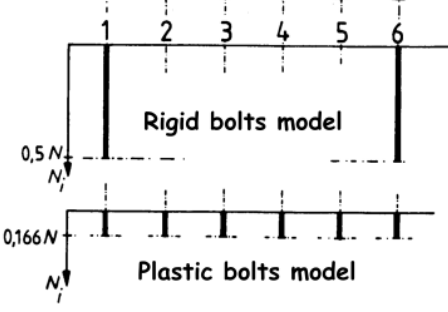

d)

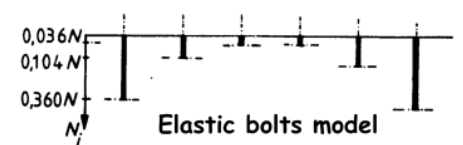

e)

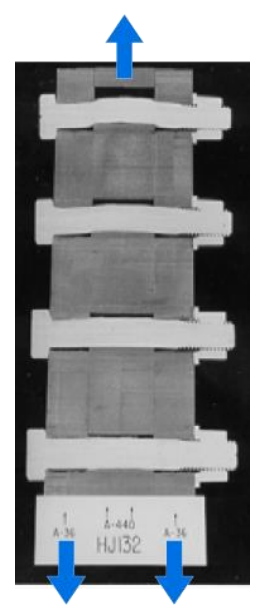

Fig. 3. Long bolted connection: a) $\div$ d) different models of load distributions in six bolts connection [1], e) example of an uneven force distribution - sawed outer section of bolted joint after the destructive test [4]

The problem of uneven stress on the joints' length also occurs in continuous welded joints. As in the case of long bolted connection, a range of the stress variation along the weld length (when lap joint is longitudinally loaded) depends on both relative stiffness of the connectors (welds) and the stiffness of the joined elements. The relationship between the weld length and the distribution of stresses along the fillet weld has been investigated by Feder [4] and presented depending on the length of connection as shown in Fig. 4. Three different cases were distinguished, when the connection length $l$ is lower, equal and higher then limited length of the weld (Fig. 4 c-e). 


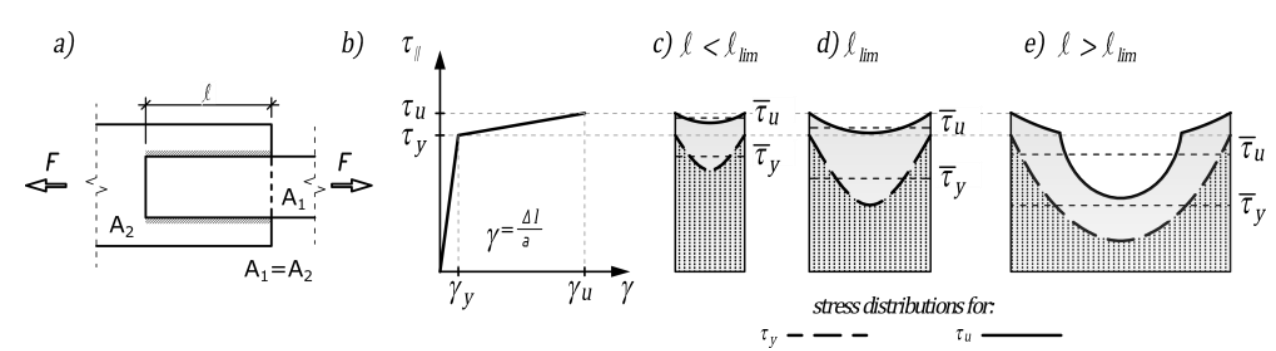

Fig. 4. Distribution of shear stress $\tau_{\|}$in a connection with long fillet weld:

a) connection schema, b) non-linear material model, c), d), e) elastic and plastic stresses distribution on the connection length when respectively yield strength $\tau_{\mathrm{y}}$ and ultimate strength $\tau_{\mathrm{u}}$ are obtained

Distribution of forces in transition zone were discussed in details with additional parametric analysis of main factors having quantitative and qualitative influence on the forces redistribution in paper [6].

\section{DESTRUCTIVE TESTS}

The distribuiton of forces in long connections analysis, by analogy with bolted and welded connections, was the point of references when designing the transition zone of hybrid beam. Similar force in each connector was the key point constituting the proper and acceptable solution and one of the main objectives of the destructive test, which was performed at the Civil Engineering Research Laboratory in Wrocław University of Technology, Poland.

\subsection{Specimens for destructive test}

The boundary conditions, such as geometry or materials, and testing procedures were established by analogy to the test of the shear connectors given in Eurocode EN 1994-1-1. The cross section of the beam changes over the length, which means that on the one end of the beam there is a concrete section and on the other side composite one. To be more specific, the cross section shape changes from concrete rectangular shape $650 \times 400 \mathrm{~mm}$ to composite T-shape section with reinforced concrete slab $650 \times 200 \mathrm{~mm}$ and reinforced concrete web $200 \times 200$ $\mathrm{mm}$ (Fig. 5). The steel part was made of welded plates fabricated to simulate half of IPE 500 profile. The transition zone was fabricated with 8 connectors, which were the $50 \mathrm{~mm}$ diameter holes in steel web spaced $125 \mathrm{~mm}$ apart. In transition zone, each rebar from bottom reinforcement was folded and perforated the hole. 


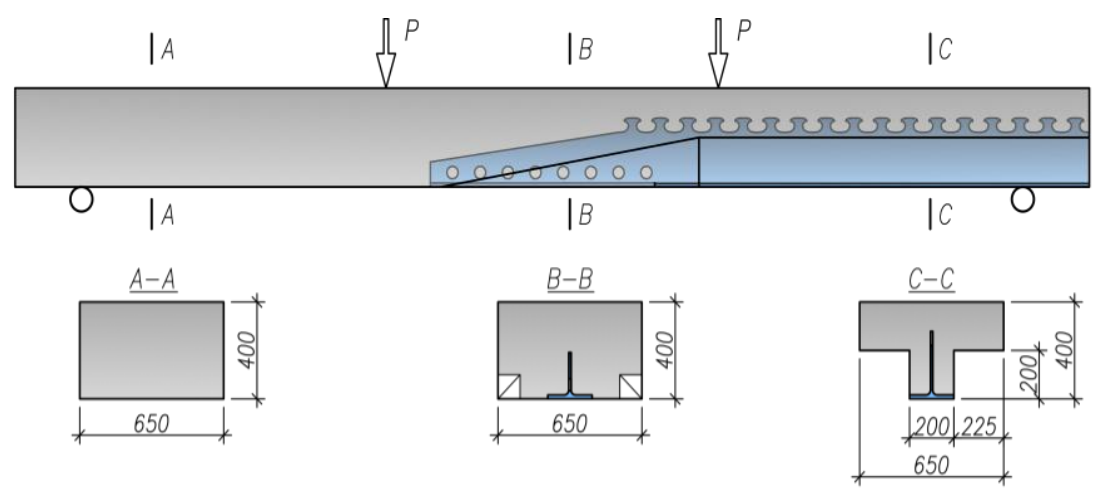

Fig. 5. General layout of beam specimen - front view with characteristics cross sections

The destructive tests were conducted on a simply supported beam subjected to a 4-point-bending test. On the length of the transition zone, between the concentrated forces, constant bending moment with no shear forces is obtained connecters do not transmit the longitudinal shear. The theoretical span of beam was $4.250 \mathrm{~m}$ and total length $4.850 \mathrm{~m}$ (Fig. 5). Two concentrated forces, with $1.500 \mathrm{~m}$ spacing, were arranged symmetrically at a distance of $1.375 \mathrm{~m}$ from the supports. The vertical monotonic load was applied to the specimen, using a hydraulic jack with a maximum capacity of $6 \mathrm{MN}$.

While testing the deflection, slips and strains at key locations on the beam were measured by means of respectively inductive sensors LVDT and strain gauges. Details of destructive test concerning test layout, specimen instrumentation and experimental program were presented in [5].

\subsection{Test result and failure model}

The first crack was visually detected at the level of $250 \mathrm{kN}$, at the bottom part of the specimens, near the concentrated force on concrete section.

As the load increases, typical flexural cracks propagate to the neutral axis of the beam's cross-section. In the final stage, plastic hinge was obtained resulting in exceeding the ultimate compressive strains in top concrete, what lead to its brittle cracking (Fig. 6). At the same time, the bottom external reinforcement in transition zone was pulled out of the concrete in vertical direction.

\subsection{Analysis of the test's results}

Due to experiment results, the ultimate bending resistance both of composite and concrete section were sufficient to carry out the destructive test aimed to transition zone failure. 

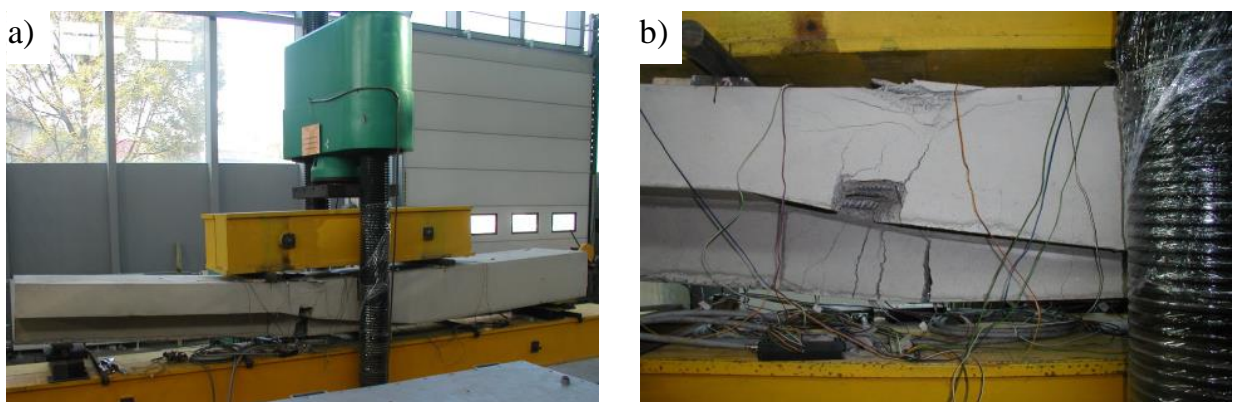

Fig. 6. Tests set up with the failure of beam specimens: a) general arrangement of specimen after destructive tests, b) part of transition zone after experimental tests [5]

The ultimate load is $854 \mathrm{kN}$ which corresponds to deflection at middle-span of 55 $\mathrm{mm}$. The initial displacement response is quasilinear but the on-set of nonlinearity occurred at relatively low load which is about $60 \%$ of resistance. Thus, load value $P=500 \mathrm{kN}$ and corresponding deflection $u=20 \mathrm{~mm}$ may be assumed as a limit of elastic range.

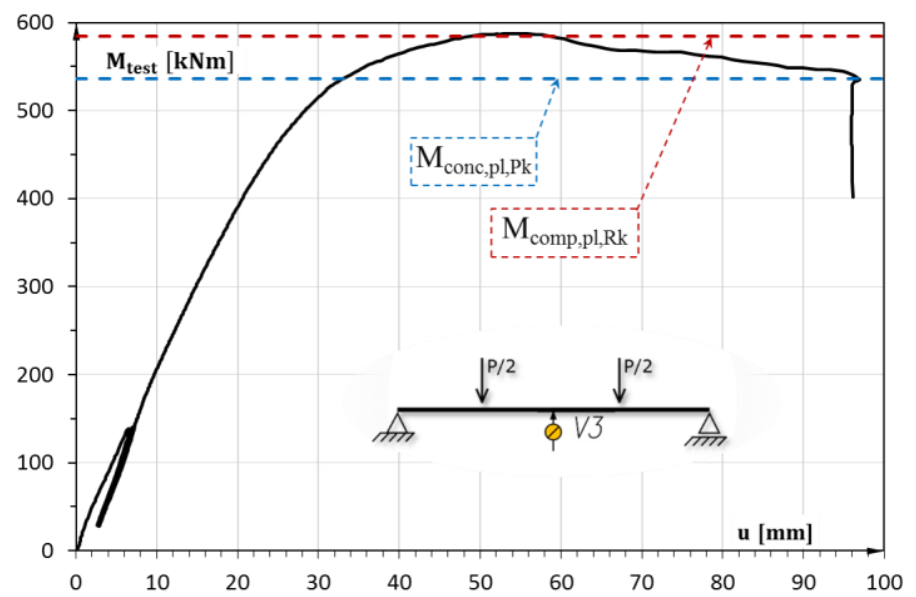

Fig. 7. Maximum bending moment to deflection relationship. Additional characteristic values of the resistance moment were presented - description in text

Bending resistance of reinforced concrete section and steel-concrete composite section were calculated. For each section characteristic resistance $\mathbf{M}_{R k, i}$ was estimated and compared with the tests results $M_{\text {test }}$. Curve presenting the relationship between maximum bending moment and deflection were obtained and shown in Figure 7. The reference value $\mathbf{M}_{R k, i}$ respectively for $\mathbf{M}_{R k, c o n c}, M_{R k, c o m p}$ curve is:

$M_{\text {conc }, p l, R k} \quad-$ plastic, characteristic value of the resistance moment of reinforced concrete section, 
$M_{\text {comp }, p l, R k} \quad$ - plastic, characteristic value of the resistance moment of composite section.

The characteristic values were calculated based on both nominal value of the yield strength of steel $f_{y k}$ and characteristic value of the cylinder compressive strength of concrete $f_{c k}$. The plastic stress distribution for analytical calculation was assumed.

Obtained ultimate resistance of transition zone $M_{\text {test, } \max }=587 \mathrm{kNm}$ is similar to estimated characteristic value of resistance moment of composite section $M_{c o m p, p l, R k}=584 \mathrm{kNm}$ and about $10 \%$ higher than estimated characteristic value of resistance moment of concrete section $M_{c o n c, p l, R k}=536 \mathrm{kNm}$. The transition zone has sufficient capacity to transfer bending between composite and concrete sections clearly, especially taking into account that transition zone is used to be designed near zero bending moment areas.

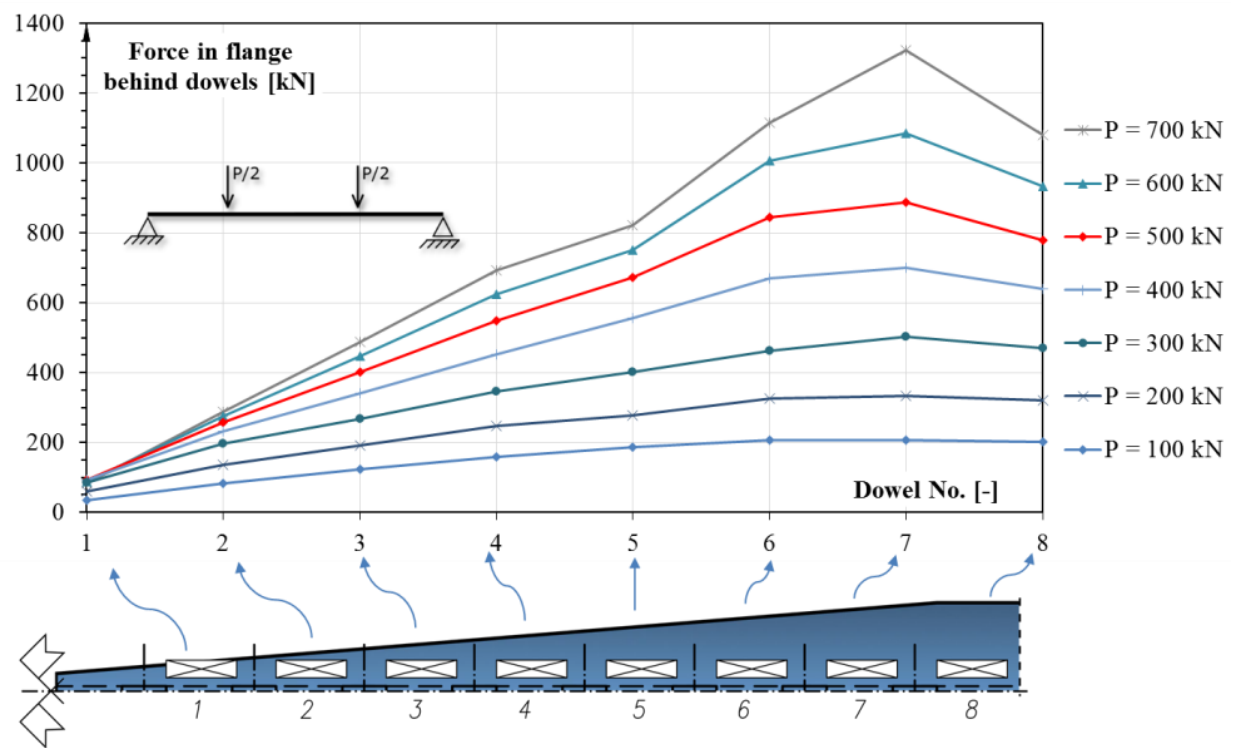

Fig. 8. Forces in flange measured behind each dowel (load range: 100-700kN)

The pair of stain gauges after each hole connector (dowel) were used to calculate the internal force at each load stage. The force in flange corresponding to the dowel number is presented in Figure 8. The linear increase of cross-section of steel element results in similar force in each dowel on every load stage. The long connections effect, which results in uneven force in connectors, was successfully and significantly reduced. The first seven dowels transfer about $1.3 \mathrm{MN}$ from concrete part to steel flange. The measured force in each dowel can be estimated as $200 \mathrm{kN}$ except the first one for which measured force is $100 \mathrm{kN}$. 


\section{CONCLUSION}

The newest studies concerning bending capacity of transition zone were presented. The problem of long connections which is typical of steel structures and which results in uneven distribution of forces was taken into account when preparing the specimens. That is why, both web and flange of steel element in transition zone change their cross-sections (stiffness) linearly from full section to almost zero. Destructive test results confirm that assumed design solutions could be applied in constructions. The relative flexural load bearing capacity is 587 $\mathrm{kNm}$ which is sufficient in order to apply the solution in constructions. The expected failure mechanism was obtained and the results indicate an appropriate force redistribution between the holes in the ultimate limit state. The following paper presents an excerpt of $\mathrm{PhD}$ dissertation developed by MSc. Piotr Kozioł.

\section{REFERENCES}

1. Biegus A.: Połaczenia śrubowe. Wrocław: Wydawictwo Naukowe PWN, 1997.

2. Berthellemy, J. Lorenc, W. Mensinger, M. Rauscher, S. Seidl, G.: Zum Tragverhalten von Verbunddübeln, Teil 1: Tragverhalten unter statischer Belastung. Stahlbau 80, Heft 3: 172-184, 2011.

3. Berthellemy, J. Lorenc, W. Mensinger, M. Ndogmo, J. Seidl, G.: Zum Tragverhalten von Verbunddübeln, Teil 2: Ermüdungsverhalten. Stahlbau 80, Heft 4: 256-267, 2011.

4. Feder D., Werner G.: Ansätze zur Traglastberechnung von Schweissverbindungen des Stahlbaus. Schweissen und Schneiden 29, Heft 4, 1977.

5. Kozioł P., Kożuch M. P., Lorenc W., Rowiński S.: Innovative solution of transition zone in steel-concrete hybrid beam, Recent progress in steel and composite structures: proceedings of the XIII International Conference on Metal Structures (ICMS2016), Zielona Góra, Poland, 15-17 June 2016, , pp. 137-142, 2016.

6. Kozioł P., Lorenc W.: Analiza połaczenia stali $z$ betonem $w$ strefie przejściowej dźwigara zespolonego stalowo-betonowego, Materiały Budowlane, vol. nr 5, no. Journal Article, pp. 97-98, 2016.

7. Leonhardt F., Andrä W., Andrä H.-P. \& Harre W.: Neues, vorteilhaftes Verbundmittel für Stahlverbund-Tragwerke mit hoher Dauerfestigkeit. Betonund Stahlbetonbau 82, Heft 12: 325-331, 1987.

8. Lorenc W., Kubica E., Kożuch M.: Testing procedures in evaluation of resistance of innovative shear connection with composite dowels. Archives of Civil and Mechanical Engineering 10/2012 No. 3: 51-63, 2012. 
9. Lorenc W., Kożuch M., Seidl G.: Zur Grenztragfähigkeit von Verbunddübeln mit Klothoidenform. Stahlbau 82, Heft 3: 196-207, 2013.

10. Lorenc W., Kożuch M., Rowiński S.: The behavior of puzzle-shaped composite dowels - part I: experimental study. Journal of Constructional Steel Research. 101/2014: 482-499, 2014.

11. Lorenc W., Kożuch M., Rowiński S.: The behavior of puzzle-shaped composite dowels - part II: theoretical investigations. Journal of Constructional Steel Research. 101/2014: 500-518, 2014.

12. Seidl G., Stambuk M., Lorenc W., Kołakowski T., Petzek E.: Wirtschaftliche Verbundbauweisen im Brückenbau - Bauweisen mit Verbunddübelleisten. Stahlbau 82, Heft 7: 510-521, 2013.

\section{NOŚNOŚĆ POŁĄCZEŃ W STREFIE PRZEJŚCIOWEJ W STALOWO-BETONOWYCH BELAKACH HYBRYDOWYCH}

\section{Streszczenie}

$\mathrm{W}$ artykule przedstawiono zagadnienie kształtowania połączenia elementu stalowego z elementem betonowym w strefie przejściowej belki hybrydowej. Strefa ta może być wykorzystana m.in. w nowatorskich rozwiązaniach zespolonych dźwigarów mostowych, umożliwiając ich swobodne kształtowanie podłużne poprzez płynną zmianę pomiędzy przekrojem zespolonym a betonowym. Przedstawiono różne rozwiązania konstrukcyjne strefy przejściowej oraz poruszono problem nierównomiernego rozdziału sił w połączeniach długich, jako jednego $\mathrm{z}$ głównych czynników wpływających na kształtowanie połączenia elementu ze stali konstrukcyjnej z konstrukcją betonową. Prototypowe rozwiązanie strefy przejściowej opisano na podstawie przeprowadzonego badania niszczącego omawiając najnowsze wyniki tego badania oraz analizując model zniszczenia i redystrybucję sił na długości strefy.

Słowa kluczowe: $\quad$ strefa przejściowa, belka hybrydowa, łączniki perfobond, badania niszczące, konstrukcje zespolone.

Editor received the manuscript: 06.07.2016 